\title{
RELASI OTONOMI DAERAH TERHADAP PENINGKATAN PARTISIPASI PUBLIK, GOOD GOVERNANCE DAN DEMOKRATISASI
}

\section{Choirul Mahfud}

\section{ABSTRAK}

\begin{abstract}
Tebijakan otonomi daerah pada hakekatnya upaya pemberdayaan dan pendemokrasian kehidupan masyarakat dengan otonomi daerah. Daerah senantiasa terus berusaha 1 mendorong terciptanya pemerintahan bersih dengan menyelenggarakan uji akuntabilitas publik dan mengawasi praktik korupsi baik yang dilakukan pejabat maupun birokrat. Lebih dari itu, otonomi daerah juga mendorong terwujudnya masyarakat demokratis dengan mengusung semangat nilai-nilai demokrasi.
\end{abstract}

\section{Kata kunci: Otonomi daerah, partisipasi publik, good-governance, demokrasi dan demokratisasi}

\section{PENDAHULUAN}

Sejak bergulirnya gelombang reformasi hingga hari ini, otonomi daerah (otoda) masih menjadi salah satu topik utama yang ramai diperbincangkan banyak kalangan, baik pejabat, birokrat, pemerintah, lembaga perwakilan rakyat, kalangan akademisi, aktivis NGO, pelaku ekonomi, masyarakat awam maupun praktisi media massa. Dengan ragam sudut pandang berbeda, semua pihak berbicara dan memberikan komentar tentang otoda menurut pemahaman dan persepsinya masingmasing (Ehrenhalt, 2006). Otonomi daerah bukanlah hal baru bagi masyarakat Indonesia. Sebab, sejak berdirinya Negara Kesatuan Republik Indonesia, konsep otonomi daerah sudah digunakan dalam penyelenggaraan pemerintahan di daerah (Asfar, 2001).

Bahkan sebelum merdeka pada masa pemerintahan kolonial Belanda, prinsip-prinsip otonomi sebagian sudah diterapkan dalam penyelenggaraan pemerintahan. Bila ditilik ke belakang, dimulai sejak awal kemerdekaan sampai sekarang telah terdapat beberapa peraturan perundang-undangan yang mengatur tentang kebijakan otonomi daerah. UU 1/1945 menganut sistem otonomi daerah rumah tangga formil. UU 22/1948 memberikan hak otonomi dan memberi wewenang yang seluas-luasnya kepada daerah. Selanjutnya UU 1/1957 menganut sistem otonomi yang seluasluasnya. Kemudian UU 5/1974 menganut prinsip otonomi daerah yang nyata dan bertanggungjawab, dan muncul peraturan baru, UU 22 Tahun 1999. Hingga akhirnya saat ini direvisi kembali menjadi UU 32/2004 mengenai pemerintahan daerah dan wewenang yang diembannya sesuai prinsip-prinsip otonomi daerah yang luas, nyata dan bertanggungjawab (Oetama, 2001).

Otonomi daerah yang dilaksanakan saat ini adalah otonomi daerah yang berdasarkan kepada Undang-Undang Nomor 32 tahun 2004 sebagai revisi UU 22 Tahun 1999 tentang Pemerintahan Daerah. Menurut UU ini, otonomi daerah dipahami sebagai kewenangan 
daerah otonom untuk mengatur dan mengurus kepentingan masyarakat setempat menurut prakarsa sendiri berdasarkan aspirasi masyarakat sesuai dengan peraturan perundang-undangan. Sedangkan prinsip otonomi daerah yang digunakan adalah otonomi daerah yang luas, nyata dan bertanggung jawab. Kewenangan otonomi yang luas adalah keleluasaan daerah untuk menyelenggarakan pemerintahan yang mencakup kewenangan semua bidang pemerintahan, kecuali kewenangan di bidang politik luar negeri, pertahanan keamanan, peradilan, moneter, fiskal dan agama serta kewenangan bidang lain yang ditetapkan dengan Peraturan Pemerintah.

Selain itu, yang dimaksud dengan otonomi nyata adalah keleluasaan daerah untuk menyelenggarakan kewenangan pemerintahan di bidang tertentu yang secara nyata ada dan diperlukan serta tumbuh hidup, dan berkembang di daerah. Sedangkan yang dimaksud dengan otonomi yang bertanggung jawab adalah berupa perwujudan pertanggungjawaban sebagai konsekuensi pemberian hak dan kewenangan kepada daerah dalam wujud tugas dan kewajiban yang dipikul oleh daerah dalam mencapai tujuan pemberian otonomi, berupa peningkatan pelayanan publik, terciptanya good-governance dan kesejahteraan masyarakat yang semakin baik, pengembangan kehidupan demokrasi, keadilan, pemerataan, pemeliharaan hubungan yang serasi antara pusat dan daerah dan sebaliknya dalam rangka untuk menjaga keutuhan Negara Kesatuan Republik Indonesia (Nurudin, 2005).
Barangkali sudah banyak hasil penelitian yang mengupas bahasan otonomi daerah. Akan tetapi, dalam tulisan ini, penulis bermaksud ingin menyampaikan salah satu topik yang paling sering terlewatkan dalam penelitian otonomi daerah, yaitu masalah keterkaitan otonomi dengan peningkatan pelayanan publik, terciptanya goodgovernance dan demokrasi. Topik ini nampaknya masih jarang dibahas secara tuntas, sehingga saat ini perlu perhatian bersama. Memang ada sebagian kecil dari masyarakat yang menyadari masalah ini, tapi sebagian besar masih cenderung tidak memperhatikan dan memahami hal tersebut secara komprehensif dan serius. Karenanya, telaah kritis disertai jalan keluar sebagai solusi amat perlu diperhatikan semua pihak dalam mengawal maju-mundurnya gerakan otonomi daerah yang tepat dan bertanggung jawab sesuai dengan peraturan dan perundang - undangan tanpa menghilangkan semangat kebersamaan dan kebutuhan lokalitas sosio-kultural.

\section{RUMUSANMASALAH}

Setelah memperhatikan hantaran di atas, maka perlu diajukan beberapa pertanyaan kritis yang perlu mendapatkan perhatian lebih serius berikuti ini :

1. Adakah relasi antara otonomi daerah dengan peningkatan partisipasi publik, penyelenggaraan good-governance dan proses demokratisasi?

2. Sudah berubahkah pola partisipasi publik sejak dilaksanakannya otonomi daerah?

3. Sudah berubahkah kinerja lembaga-lembaga pemerintah? Dan bagaimana bentuk perubahannya? 


\section{PEMBAHASAN}

Sebelum membahas lebih jauh tentang relasi otonomi daerah terhadap partisipasi publik, good-governance dan proses demokratisasi, perlu dipahami terlebih dahulu pemahaman masyarakat, khususnya di daerah, dalam memahami makna otonomi daerah. Warga di daerah pada umumnya telah mengerti meskipun pengertian tersebut tidak semuanya bisa disamakan, sebab selain masing-masing pihak memiliki cara, metode dan pendekatan dalam memahami arti otonomi daerah juga disebabkan perbedaan pengalaman dan kedudukan dalam suatu masyarakat. Namun demikian, secara umum, mereka memahami dan mengerti prinsip-prinsip yang terkait dengan otonomi daerah tersebut walaupun mereka memiliki interpretasi yang berbeda-beda. Perbedaan pengertian otonomi ini ditemukan baik di jajaran pemerintah yang setingkat maupun berbeda tingkat. Berbagai interpretasi termasuk (sumber):

1. Transfer kekuasaan/devolusi dari pemerintah pusat ke daerah. Dibandingkan dengan UU 5/1974, UU 22/1999, UU 32/ 2004 memberikan posisi yang lebih baik bagi pemerintah daerah karena sekarang mereka memiliki otoritas untuk mengelola wilayahnya, mengimplementasikan perencanaan secara bottom- up dan memiliki kebebasan dalam mengelola anggarannya, dan pada saat yang sama menjamin keutuhan negara kesatuan Republik Indonesia.

2. Peningkatan kemandirian daerah dan pemberian peluang dari pusat ke daerah untuk memanfaatkan potensi dan sumber daya lokal. Pemerintah daerah juga memiliki otoritas untuk membuat perencanaan, pelaksanaan, dan pembiayaan programprogram pembangunannya, selain berwenang untuk mengelola lembaga pemerintah dan meningkatkan kesejahteraan masyarakat berdasarkan kapasitas lokalnya.

3. Mengembalikan peran lembaga-lembaga legislatif dengan memberikan ruang lebih besar bagi DPRD dalam menjalankan peran pengawasannya. Lebih jauh lagi, diharapkan tercipta hubungan yang seiaiar antara lembaga eksekutif dan legislatif.

4. Peningkatan kesejahteraan masyarakat melalui perbaikan pelayanan pemerintah kepada masyarakat. Untuk tujuan ini, otoda mengharuskan pemerintah lokal diisi oleh pegawai yang profesional dan mumpuni.

5. Pemberdayaan masyarakat dan mendekatkan jarak antara pemerintah dengan rakyat. Pemerintah daerah (terutama eksekutif) seharusnya berperan sebagai fasilitator dalam pembentukan civil society. Untuk menjalankan peran ini perlu ada penyesuaian fungsi-fungsi pemerintah daerah.

6. Sebagai sebuah produk yang dibuat relatif terburu-buru. Sebagai akibatnya, ditemukan berbagai ketidakjelasan konsep dan inkonsistensi dalam perangkat hukum yang menyangkut otonomi daerah. Konsep otonomi daerah tidak bisa diimplementasikan secara menyeluruh karena pemerintah pusat belum menyiapkan peraturan pemerintah yang mendukungnya. Akhirnya, proses pedefinisian otonomi daerah itu sendiri belum selesai. Definisi yang tidak komplit 
dan PP yang belum disiapkan menciptakan perebutan kekuasaan antara pemerintah daerah dengan Dewan Perwakilan Rakyat di daerah.

7. Dalam implementasinya, pemerintah pusat terlihat setengah hati dalam menyerahkan otoritasnya ke daerah. Situasinya jadi nampak seperti membebaskan ikatan di leher sambil memegang buntutnya dengan kencang. Pemerintah pusat dipandang mentransfer otoritas yang menguntungkan dirinya sendiri, yaitu mengurangi otoritasnya yang selama ini dirasakan sebagai beban. Otonomi daerah dirasakan sebagai beban baru bagi pemerintah daerah dengan keterbatasan otoritas di bidang fiskal.

Menyimak uraian di atas boleh jadi optimisme pada sebagian besar elemen bangsa menjadi redup bahwa percepatan pelaksanaan otonomi daerah sekarang ini tidak mampu secara segera mewujudkan demokratisasi, good governance dan tingkat kesejahteraan yang lebih baik bagi rakyat. Hal tersebut akan berujung pada kekecewaan yang melahirkan sikap perlawanan rakyat dalam segala manifestasinya. Pemerintah yang tidak memiliki legitimasi moral dari rakyatnya mustahil dapat berjalan efektif, betapa pun programprogramnya langsung menyentuh kebutuhan rakyat. Oleh karena itu sangat beralasan jika dilakukan pengkajian kembali terhadap berbagai kebijakan yang berlaku sekarang untuk menentukan format penyelenggaraan negara/ pemerintahan yang memberi manfaat terbesar kepada rakyat.

Format daerah otonomi perlu diubah dengan membuka peluang seluas-luasnya bagi publik untuk terlibat langsung dalam penyelenggaraan urusan daerah berlandaskan kemandirian dan keswadayaan (Monoyasa, 2006). Menurut penulis, otonomisasi pemerintahan yang lebih menguntungkan bagi rakyat adalah sebagai berikut. Pertama, bentuk daerah otonomi adalah daerah provinsi/ setingkat provinsi yang meliputi cakupan wilayah yang menjamin manajemen pemerintahan bekerja efektif dan efisien. Kedua, daerah kabupaten dan kota menjadi pemerintahan administratif di bawah daerah provinsi dengan bentuk kelembagaan yang efisien. Ketiga, lembaga representasi rakyat pada pemerintahan kabupaten/ kota berlandaskan kemandirian dan keswadayaan.

Lembaga ini melakukan kontrol terhadap jalannya pemerintahan sehari-hari, bersama eksekutif menetapkan kebijakan operasional, menyetujui usulan budget dari eksekutif kabupaten/kota kepada daerah provinsi, mengangkat dan memberhentikan pimpinan puncak kabupaten/kota. Operasional lembaga ini dibiayai pemerintah tetapi orangorangnya sebagai wakil rakyat tidak memperoleh pembiayaan pemerintah negara. Tentu timbul pertanyaan, apakah ada yang bersedia menjadi wakil rakyat di tingkat kabupaten dan kota?

Selama ini lembaga RT/RW dan lembaga adat tetap eksis dalam dinamikanya masingmasing meskipun tidak memperoleh pembiayaan pemerintah. Justru masalah keterwakilan rakyat ini menjadi syarat konflik ketika pemerintah/negara mengalokasikan dana secara kurang bijak. Contohnya, proses pemilihan anggota Badan Perwakilan Desa di Jawa Timur atau anggota Dewan Kelurahan di 
DKI Jaya hingar-bingar oleh intrik-intrik saling menjatuhkan di antara para calon anggota.

Dalam konteks seperti ini, maka kehadiran kebijakan otonomisasi membawa beberapa keuntungan, diantaranya adalah:

a). Gejolak politik/politisasi pemerintahan pada level akar rumput dapat diabsorbsi pada titik minimal,

b). Terpilihnya wakil-wakil rakyat dengan integritas teruji,

c). Efisiensi penggunaan dana untuk pembiayaan birokrasi dan "biaya demokrasi" demokratisasi

Secara akumulatif ketiganya mendukung percepatan terwujudnya good governance yang mensejahterakan rakyat (MacAndrews, 1986). Tentu saja perlu dibuat manajemen waktu yang ketat dan rasional untuk menerapkan model ini, sehingga peralihan dari model sekarang tidak menimbulkan gejolak/ biaya sosial politik yang tidak perlu. Perlu dibuat cetak biru yang rinci untuk disosialisasikan secara luas kepada setiap lapisan rakyat sehingga mayoritas rakyat dapat menilai secara langsung kelebihan/ kekurangannya dibandingkan dengan versi otonomi daerah yang diterapkan sekarang. Di sini mutlak harus dihindarkan pretensi-pretensi untuk segera memutuskan pilihan tertentu berwawasan jangka pendek/populis yang mengakibatkan bongkar pasang model berkali-kali. Amerika membutuhkan waktu puluhan tahun untuk sampai pada model pemerintahannya sekarang.

Agenda penting berikutnya adalah jumlah aparat birokrasi yang terlalu besar. Langkah perampingan birokrasi mungkin harus segera dilakukan untuk menyehatkan kehidupan birokrasi. Pengurangan aparat melalui rekrutmen baru sangat selektif dan jumlahnya lebih kecil dari aparat yang pensiun, tidak akan pernah efektif memperbaiki kinerja birokrasi. Alternatif model rasionalisasi yang elegan dan meminimalkan timbuInya biaya sosial, misalnya;

1). Dilakukan rasionalisasi terhadap kelebihan jumlah pegawai dengan pesangon memadai tanpa hak pensiun. Alternatif sumber pembiayaan tentu dari hutang luar negeri karena kecil kemungkinan mendapatkannya di dalam negeri. Selain itu rasionalisasi secara bertahap juga bisa mengendalikan potensi dampak inflasi yang ekstrim;

2). Kelebihan pegawai secara serentak dinonaktifkan dengan menerima gaji, tunjangan anak/istri/suami, tunjangan beras secara penuh ditambah persentase tertentu dari tunjangan resmi lainnya.

3). Rasionalisasi dengan menggunakan kombinasi dari dua cara di atas dikaitkan dengan usia pegawai. Pegawai dengan usia 50 tahun ke atas diterapkan cara kedua. Sedangkan, pegawai yang berusia di bawah 50 tahun dibebaskan memilih salah satu dari cara di atas.

Langkah rasionalisasi pegawai akan memudahkan perombakan terhadap sistem dan prosedur atau mendesain bentuk kelembagaan yang memiliki fleksibilitas tinggi dalam merespons dinamika masyarakat. Komitmen dalam mendesain sistem dan prosedur dalam konteks eksternal adalah memegang teguh asas-asas pelayanan publik yang baik. Kondisi di masa lalu yang mengharuskan masyarakat jungkir balik akibat rendahnya kualitas kinerja dan akuntabilitas birokrasi harus dirombak menjadi birokrasi yang santun, egaliter, 
akuntabel. Sedangkan dalam konteks internal, desain sistem dan prosedur seyogyanya mengadopsi praktik-praktik dan teori yang terbukti mendukung terciptanya aparat birokrasi yang profesional. Perombakan sistem kepangkatan, jabatan, penghargaan dan penghukuman, pengembangan pegawai perlu dilakukan secara konsepsional. Selain itu, seyogyanya nilai-nilai budaya yang cenderung dapat merusak sistem dan prosedur sejalan perlu direformasi.

\section{Partisipasi Publik}

Pada prinsipnya, otonomi daerah diharapkan dapat lebih meningkatkan kualitas partisipasi dan pelayanan publik, memperbaiki derajat kesejahteraan serta kelayakan hidup rakyat, di mana pemerintahan dan pembangunan dikelola dalam proses-proses yang demokratis (Kartasasmita, 2006). Dalam proses-proses pengelolaan daerah seperti itu, pemerintah daerah memiliki ruang bebas untuk berkreatifitas membuat kebijakan yang dituangkan dalam Peraturan Daerah (Perda), dengan melibatkan stakeholders yang ada di daerahnya. Muara dari semua kebijakan pemerintah daerah tersebut, berkembang pada kesejahteraan rakyat secara berkelanjutan sebagai tujuan akhir (Demetrios, 1996).

Sayangnya, sasaran-sasaran otonomi daerah tersebut di atas belum tercapai karena berbagai hal. Di satu pihak, masih ada berbagai peraturan perundangan di tingkat pusat yang bertentangan dengan semangat otonomi daerah serta tidak menyelesaikan tumpang tindih kewenangan antar berbagai instansi pemerintah pusat. Menurut catatan dari Asosiasi Pemerintah Provinsi se-Indonesia ada
25 (dua puluh lima) undang-undang sektoral yang tidak sejalan dengan Undang-Undang Nomor 32 Tahun 2004 tentang Pemerintahan Daerah. Di sisi lain masih terdapat cukup banyak peraturan daerah yang bertentangan dengan aturan yang lebih tinggi serta tidak berorientasi kepada kepentingan umum.

Berdasarkan berbagai temuan itu, pemerintah pusat seharusnya dapat memberikan teladan dalam penyusunan peraturan perundangan yang konsisten dengan prinsip-prinsip otonomi daerah, sembari memberi pengarahan agar pembuatan perda senantiasa berorientasi pada pelayanan publik dan pembuatannya harus lebih partisipatif ketimbang instruktif. Sebagai negara yang berdasarkan hukum, pembenahan peraturan memang diperlukan dalam rangka untuk menciptakan tata kelola pemerintahan yang baik di segala tingkatan. Dengan peraturan yang konsisten, nondiskriminatif serta berorientasi pada pelayanan dan partisipasi publik terdapat peluang untuk memperbaiki kinerja birokrasi, mengatasi korupsi, serta kecenderungan primordial dan politisasi jabatan.

Dalam konteks semacam ini, otonomi daerah sangat membutuhkan dan memerlukan kemandirian bagi daerah untuk bisa terus maju dan kian berkembang di tengah kompetisi yang semakin ketat (Saputro, 2007). Sebab, di satu pihak daerah yang potensial dengan pengembangan semua sumber daya yang dimilikinya tentu mampu berkembang secara lebih cepat dibanding dengan daerah lain yang tidak memiliki sumber daya yang potensial. Di lain pihak, sumber daya tersebut tidak mutlak menjadi potensi keunggulan komparatif. Sebab, saat ini persepsi tentang keunggulan komparatif 
sudah semakin pudar karena yang terpenting justru bagaimana bisa lebih menciptakan keunggulan kompetitif.

Selain itu, secara empiris harus diakui bahwa di negara-negara yang sudah maju kehidupan demokrasinya diterapkan otonomisasi yang luas bagi pemerintah lokal (negara bagian, propinsi, teritori) untuk mengurus rumah tangga pemerintahannya, sementara pemerintah pusat hanya menangani urusan-urusan strategis/ vital dalam kerangka kesatuan negara. Otonomisasi tersebut terbukti mampu memberikan kesejahteraan material/ immaterial yang jauh lebih berkualitas dibandingkan dengan negara-negara yang tidak demokratis atau berdemokrasi setengah hati.

\section{Transparansi dan Good Governance}

Good governance dan transparansi penyelenggaraan pemerintahan, belakangan ini sudah menjadi kebutuhan yang sangat mendesak. Pertanyaannya, mengapa perlu good governance dan transparansi dalam penyelenggaraan pemerintahan daerah? Sebelum kita lebih jauh berupaya menemukan format dan konsep transparansi mungkin pertanyaan di atas perlu dijawab terlebih dahulu. Ketika seseorang mencalonkan diri sebagai Kepala Daerah maka ia akan menawarkan seperangkat janji kepada para pemilih, demikian juga para anggota legislatif yang memberikan sejumlah janji kepada konstituen.

\section{Sasaran}

penyelenggaraan pemerintahan dewasa ini seharusnya adalah kepercayaan yang diperintah terhadap pemerintah sebagai output (World Development Report, 1999/2000). Maksudnya di sini adalah yang diperintah percaya kepada pemerintah karena bukti bukan janji. Kepercayaan tersebut timbul karena pemerintah mampu dan mau untuk memenuhi janji yang telah disampaikan. Kemampuan untuk menjawab atau memenuhi janji kepada orang lain tersebut adalah tanggung jawab (responsibility). Jadi pemerintah yang bertanggung jawab adalah pemerintah yang mampu menjawab atau memenuhi janji kepada warganya. Untuk mewujudkan pertanggung jawaban pemerintah terhadap warganya salah satu cara yang perlu dilakukan adalah dengan menggunakan prinsip good governance dan uanspanansi (keterbukaan).

\section{Melalui} transparansi penyelenggaraan pemerintahan, masyarakat diberikan kesempatan untuk mengetahui kebijakan yang akan dan telah diambil oleh pemerintah. Juga melalui transparansi penyelenggaraan pemerintahan tersebut, masyarakat dapat memberikan feedback atau outcomes terhadap kebijakan yang telah diambil oleh pemerintah. Makna dari transparansi dalam penyelenggaraan pemerintahan daerah dapat dilihat dalam dua hal yaitu ; (1) salah satu wujud pertanggung jawaban pemerintah kepada rakyat, dan (2) upaya peningkatan manajemen pengelolaan dan penyelenggaraan pemerintahan yang baik dan mengurangi kesempatan praktek kolusi, korupsi dan nepotisme (KKN).

\section{Menuju Good Governance}

Beberapa waktu belakangan tengah dikembangkan dan dimasyarakatkan konsep atau ajaran tentang pemerintahan yang bersih yang bebas KKN atau pemerintahan yang bersih dan berwibawa. Ajaran tentang pemerintahan yang baik dan bersih ini memang sangat populer dan menjadi perhatian banyak kalangan yang 
lebih dikenal dengan good governance. Memang s mewujudkan pemerintahan yang bersih dan berwibawa tersebut tidak semudah membalik telapak tangan. Bayangkan saja, negara maju seperti Amerika Serikat yang juga mengembangkan good governance butuh waktu puluhan tahun, meski ia lebih memilih konsep pemerintahan yang works better and costs less.

Sejalan dengan pelaksanaan pemerintahan daerah dibawah Undang-Undang Nomor 32 Tahun 2004 sebagagi revisi UU No. 22 Tahun 1999 tentang Pemerintahan Daerah, kita semua pasti mencita-citakan suatu good governance. Semangat otonomi daerah yang luas, nyata dan bertanggung jawab di bawah UU tersebut secara ideal dapat mendorong terwujudnya good governance pada penyelenggaraan pemerintahan daerah. Semangat otonomi daerah akan memacu pelaksanaan pembangunan daerah, peningkatan pelayanan kepada masyarakat, dan mendorong tumbuh dan berkembangnya demokrasi. Hal itu mungkin saja dapat diwujudkan karena daerah (Kabupaten dan Kota) mempunyai kewenangan yang luas untuk mengatur dan mengurus kepentingan masyarakat setempat menurut prakarsa sendiri berdasarkan aspirasi masyarakat sesuai dengan peraturan perundang-undangan.

Kemudian juga didukung dengan dilakukannya perubahan terhadap struktur pemerintahan daerah dari Pemerintah Daerah yang terdiri dari Kepala Daerah (eksekutif) dengan DPRD (legislatif), menjadi pemisahan badan legislatif dari pemerintah daerah. Pemisahan eksekutif dengan legislatif akan dapat meningkatkan pengawasan pada pemerintah daerah dalam penyelenggaraan pemerintahan daerah. Badan legislatif diharapkan lebih mampu menampung dan menyuarakan aspirasi masyarakat. Sehingga kedepan diharapkan penyelenggaraan pemerintahan daerah yang baik dapat diwujudkan.

Oleh sebab itu disini perlu kita rumuskan kembali pengertian dari "penyelenggaraan pemerintahan daerah yang baik". Apakah yang dimaksud disini adalah pemerintahan daerah yang diselenggarakan sesuai dengan ketentuan peraturan perundangan yang berlaku, pemerintahan daerah yang diselenggarakan semata-mata memenuhi aspirasi rakyat semata, atau pemerintahan yang diselenggarakan dengan memperhatikan aspirasi rakyat sesuai dengan ketentuan peraturan perundangan yang berlaku (Turner \& Hulme, 1997). Menurut hemat penulis, kita perlu mempertemukan dulu persepsi tentang penyelenggaraan pemerintahan daerah yang baik.

\section{Konsep dan Aplikasi Good Governance}

Dalam tulisan ini, penulis ingin menawarkan maksud penyelenggaraan pemerintahan daerah yang baik adalah penyelenggaraan pemerintahan yang sesuai dengan aspirasi masyarakat berdasarkan ketentuan peraturan perundangan yang berlaku. Format dan konsep transparansi yang akan kita implementasikan dalam penyelenggaraan pemerintahan daerah merupakan penjabaran lebih lanjut dari salah satu azas-azas umum penyelenggaraan negara sebagaimana diatur oleh UU 28/1999 tentang Penyelenggaraan Negara yang Bersih dan 
Bebas KKN (Monoyasa, 2006). Azas keterbukaan atau transparansi dalam penyelenggaraan pemerintahan daerah adalah azas yang membuka diri terhadap hak masyarakat untuk memperoleh informasi yang benar, jujur dan tidak diskriminatif tentang penyelenggaraan pemerintahan daerah dengan memerhatikan perlindungan atas hak asasi pribadi, golongan dan rahasia negara (Laode Ida, 2002).

Penerapan azas transparansi dalam penyelenggaraan pemerintahan daerah memberikan kesempatan kepada masyarakat untuk mengetahui berbagai informasi tentang penyelenggaraan pemerintahan daerah secara benar, jujur dan tidak diskriminatif. Transparansi penyelenggaraan pemerintahan daerah adalah jaminan kesempatan bagi masyarakat untuk mengetahui "siapa mengambil keputusan apa beserta alasannya". Dalam penyelenggaraan pemerintahan daerah yang baik tuntutan adanya transparansi tidak hanya kepada pemerintah daerah (eksekutif) tetapi juga kepada DPRD (legislatif). Mengingat posisi DPRD yang cukup kuat dalam mengawasi penyelenggaraan pemerintahan daerah maka dalam setiap kegiatannya DPRD harus lebih transparan (terbuka) kepada masyarakat. Beberapa hal yang perlu menjadi perhatian pada transparansi penyelenggaraan pemerintahan daerah dari sudut DPRD adalah: (1) Rapat DPRD yang terbuka untuk umum agar dapat diinformasikan kepada masyarakat agenda dan jadwalnya, (2) Penyediaan risalah rapat-rapat terbuka bagi umum ditempat yang mudah diakses masyarakat, (3) Keputusan yang dihasilkan DPRD hendaknya dapat dipublikasikan dan disosialisasikan kepada masyarakat.
Sedangkan

transparansi penyelenggaraan pemerintahan daerah dalam hubungannya dengan pemerintah daerah perlu kiranya perhatian terhadap beberapa hal berikut: (1) publikasi dan sosialisasi kebijakan-kebijakan pemerintah daerah dalam penyelenggaraan pemerintahan daerah, (2) publikasi dan sosialisasi regulasi yang dikeluarkan pemerintah daerah tentang berbagai perizinan dan prosedurnya, (3) Publikasi dan sosialisasi tentang prosedur dan tata kerja dari pemerintah daerah, (4) Transparansi dalam penawaran dan penetapan tender atau kontrak proyek-proyek pemerintah daerah kepada pihak ketiga. (5) Kesempatan masyarakat untuk mengakses informasi yang jujur, benar dan tidak diskriminatif dari pemerintah daerah dalam penyelenggaraan pemerintahan daerah. Selanjutnya dalam penyusunan peraturan daerah yang menyangkut hajat hidup orang banyak hendaknya masyarakat sebagai stakeholders dilibatkan secara proporsional. Hal ini disamping untuk mewujudkan transparansi juga akan sangat membantu pemerintah daerah dan DPRD dalam melahirkan peraturan daerah yang accountable dan dapat menampung aspirasi masyarakat.

\section{Demokratisasi dan Prospek Otonomisasi}

Sebagian kalangan menilai bahwa kebijakan otonomi daerah merupakan salah satu kebijakan otonomi daerah yang terbaik yang pernah ada di republik ini. Prinsip-prinsip dan dasar pemikiran digunakan dianggap sudah cukup memadai dengan kondisi dan kebutuhan masyarakat dan daerah (Gunawan, 2005). Kebijakan otonomi daerah yang pada hakekatnya adalah upaya pemberdayaan dan pendemokrasian kehidupan masyarakat 
diharapkan dapat memenuhi aspirasi berbagai pihak dalam konteks penyelenggaraan pemerintahan negara serta hubungan pusat dan daerah (Jha\&Mathur, 1999). Jika kita memerhatikan prinsip-prinsip penyelenggaraan otonomi daerah dapat diperkirakan prospek ke depan dari otonomi daerah. Untuk mengetahui prospek tersebut dapat dilakukan dengan menggunakan berbagai pendekatan. Salah satu pendekatan yang kita gunakan di sini adalah aspek ideologi, politik, sosial budaya dan pertahanan keamanan.

Dari aspek ideologi, sudah jelas dinyatakan bahwa Pancasila merupakan pandangan, falsafah hidup dan sekaligus dasar negara. Nilai-nilai Pancasila mengajarkan antara lain pengakuan keTuhanan, semangat persatuan dan kesatuan nasional, pengakuan hak azasi manusia, demokrasi, dan keadilan dan kesejahteraan sosial bagi seluruh masyarakat. Jika kita memahami dan menghayati nilai-nilai tersebut maka dapat disimpulkan bahwa kebijakan otonomi daerah dapat diterima dalam penyelenggaraan kehidupan berbangsa dan bernegara. Melalui otonomi daerah nilai-nilai luhur Pancasila tersebut akan dapat diwujudkan dan dilestarikan dalam setiap aspek kehidupan bangsa Indonesia .

Dari aspek politik, pemberian otonomi dan kewenangan kepada daerah merupakan suatu wujud dari pengakuan dan kepercayaan pusat kepada daerah. Selanjutnya kondisi akan mendorong tumbuhnya dukungan daerah terhadap pusat dimana akhirnya akan dapat memperkuat persatuan dan kesatuan bangsa. Kebijakan otonomi daerah sebagai upaya pendidikan politik rakyat akan membawa dampak terhadap peningkatan kehidupan politik di daerah.
Dari aspek ekonomi, kebijakan otonomi daerah yang bertujuan untuk pemberdayaan kapasitas daerah akan memberikan kesempatan bagi daerah untuk mengembangkan dan meningkatkan perekonomiannya. Peningkatan dan pertumbuhan perekonomian daerah akan membawa pengaruh yang signifikan terhadap peningkatan kesejahteraan rakyat di daerah. Melalui kewenangan yang dimilikinya untuk mengatur dan mengurus kepentingan masyarakat, daerah akan berupaya untuk meningkatkan perekonomian sesuai dengan kondisi, kebutuhan dan kemampuan. Kewenangan daerah melalui otonomi daerah diharapkan dapat memberikan pelayanan maksimal kepada para pelaku ekonomi di daerah, baik lokal, nasional, regional maupun global.

Dari aspek sosial budaya, kebijakan otonomi daerah merupakan pengakuan terhadap keanekaragaman daerah, baik itu suku bangsa, agama, nilai-nilai sosial dan budaya serta potensi lainnya yang terkandung di daerah. Pengakuan pusat terhadap keberagaman daerah merupakan suatu nilai penting bagi eksistensi daerah. Dengan pengakuan tersebut daerah akan merasa setara dan sejajar dengan suku bangsa lainnya, hal ini akan sangat berpengaruh terhadap upaya mempersatukan bangsa dan negara. Pelestarian dan pengembangan nilai-nilai budaya lokal akan dapat ditingkatkan dimana pada akhirnya kekayaan budaya lokal akan memperkaya khasanah budaya nasional.

Selanjutnya dari aspek pertahanan dan keamanan, kebijakan otonomi daerah memberikan kewenangan kepada masing- 
masing daerah untuk memantapkan kondisi ketahanan daerah dalam kerangka ketahanan nasional. Pemberian kewenangan kepada daerah akan menumbuhkan kepercayaan daerah terhadap pusat. Tumbuhnya hubungan dan kepercayaan daerah terhadap pusat akan dapat mengeliminir gerakan separatis yang ingin memisahkan diri dari Negara Kesatuan Republik Indonesia .

Memperhatikan pemikiran dengan menggunakan pendekatan aspek ideologi, politik, sosal budaya dan pertahanan keamanan, secara ideal kebijakan otonomi daerah merupakan kebijakan yang sangat tepat dalam penyelenggaraan pemerintahan di daerah. Hal ini berarti bahwa kebijakan otonomi daerah mempunyai prospek yang bagus di masa mendatang dalam menghadapi segala tantangan dalam penyelenggaraan kehidupan bermasyarakat, berbangsa dan bernegara. Namun demikian prospek yang bagus tersebut tidak akan dapat terlaksana jika berbagai kendala dan tantangan yang dihadapi tidak dapat diatasi dengan baik. Untuk dapat mewujudkan prospek otonomi daerah di masa mendatang tersebut diperlukan suatu kondisi yang kondusif diantaranya yaitu:

1. Adanya komitmen politik dari seluruh komponen bangsa terutama pemerintah dan lembaga perwakilan untuk mendukung dan memperjuangkan implementasi kebijakan otonomi daerah.

2. Adanya konsistensi kebijakan penyelenggara negara terhadap implementasi kebijakan otonomi daerah.

3. Kepercayaan dan dukungan masyarakat serta pelaku ekonomi dalam pemerintah dalam mewujudkan cita-cita otonomi daerah.

Dengan kondisi tersebut bukan merupakan suatu hal yang mustahil otonomi daerah mempunyai prospek yang sangat cerah di masa mendatang. Kita berharap melalui dukungan dan kerjasama seluruh komponen bangsa kebijakan otonomi daerah dapat dilaksanakan dalam penyelenggaraan pemerintahan di daerah.

\section{SIMPULAN}

Dari paparan di atas, bisa ditarik beberapa kesimpulan sebagai berikut:

1. Sejak berlakunya otonomi daerah, ada relasi timbal balik yang positif antara otonomi daerah dan peningkatan partisipasi publik. Indikasinya, bila dibandingkan dengan sebelum diberlakukannya otonomisasi, kini lebih banyak warga kabupaten kota yang berpartisipasi/ terlibat dalam roda pemerintahan.

2. Transparansi dan akuntabilitas baik dalam pemda-pemda maupun dewan-dewan legislatif nampak mulai berjalan, meski tingkat akuntabilitas, transparansi dan penyelenggaraan good-governance sangat bervariasi.

3. Dengan otonomi daerah pula, banyak pejabat pemda pada umumnya sadar bahwa tindakan dan perilakunya perlu sesuai dengan nilai-nilai demokrasi. 


\section{DAFTAR PUSTAKA}

Asfar, Muhammad (2001). Implementasi Otonomi Daerah. Jakarta: Penerbit PusdehamCPPS-CSSP

Demetrios, Argyriades (1996). Neutrality and Professionalism in The Public Service. London: MacMillan Press. Ltd

Ehrenhalt, Alan (2006). Demokrasi Dalam Cermin; Politik Akar Rumput dan Reformasi di Amerika Serikat. Koesalah Toer, penerjemah. Jakarta: Yayasan Obor Indonesia dan Freedom Institute

Ida, Laode (2002). Otonomi Daerah dalam Interaksi Kritis Stakeholders. Jogjakarta: PSPK

Jha, SN dan Mathur, P.C (1999). Decentralization and Local Politics. New Delhi: Sage Publications

MacAndrews, Colin (1986). Central Government and Local Development in Indonesia. Singapore: Oxford University Press

Monoyasa, I Wayan (2006). Mungkinkah Good Governance terwujud di Era Otonomi Daerah? dalam http : ://www.goodgovernance-bappenas.go.id/archive_wacana/ kliping_wawasan/Klip_wsn_2006/wawasan_58.htm

Nurudin (2005). Sistem Komunikasi Indonesia. Jakarta: PT. Raja Grafindo Persada

Saputra, Edy Purwo (2007). Social - Political (Ost Pemekaran Daerah dalam http : www.seputarindonesia.com/edisicetak/opini/socialpolitical_costpemekaran_daerah_2.htm

Oetama, Jakob (2001). Berpikir Ulang tentang ke-Indonesia-an. Jakarta: Penerbit Buku Kompas

Turner, Mark dan Hulme, David (1997). Governance, Administration and Development. London: Macmillan Press. Ltd

World Development Report (199/200). Chapter 5. Decentraliation Rethiking Goverment. dalam http ://www.worldbank.org/wds/2000/fullreport.htm 